\title{
Emission of Nitric Oxide (NO) From Tropical Forest Soils and Exchange of NO Between the Forest Canopy and Atmospheric Boundary Layers
}

\author{
PETER S. BaKWIN, ${ }^{1}$ STEVEn C. WOFSY, ${ }^{1}$ SONG-Mitao Fan, ${ }^{1}$ \\ Michael Keller, ${ }^{2}$ SUSAN E. TRUMBORE, ${ }^{3}$ AND JOSE MARIA DA COSTA ${ }^{4}$
}

\begin{abstract}
Emissions of NO from soils in the Amazon rain forest were measured at 66 locations (224 measurements) using an enclosure technique, and continuous vertical profiles of $\mathrm{NO}$ and $\mathrm{O}_{3}$ were measured between the ground and $41-\mathrm{m}$ altitude. Fluxes of NO averaged $8.9( \pm 1.5) \times 10^{9}$ molecules $\mathrm{cm}^{-2} \mathrm{~s}^{-1}$ from the dominant (yellow clay) soils of the region, with larger fluxes $\left(33.7( \pm 6.5) \times 10^{9}\right.$ molecules $\left.\mathrm{cm}^{-2} \mathrm{~s}^{-1}\right)$ observed from adjacent white sand soils. Fluxes from clay soils were lower by more than a factor of 5 than fluxes observed during the dry season at a nearby site. Low soil emission rates were reflected in lower concentrations of NO at the top of the forest canopy in the wet season, only 30-50 pptv (parts per trillion by volume) during the daytime. The measured fluxes are consistent with chemical mass balances for NO within the forest canopy, calculated from the NO and $\mathrm{O}_{3}$ profiles taken at night, and with observations of NO between 150 and $5000 \mathrm{~m}$ altitude (A. L. Torres and K. R. Hooks, unpublished manuscript, 1989). Measurements of NO emission rates from soil plots fertilized using $\mathrm{NaNO}_{3}, \mathrm{NH}_{4} \mathrm{Cl}$ or sucrose indicated that a reductive pathway (denitrification) may have been primarily responsible for production of the NO released by both clay and sand soils.
\end{abstract}

\section{INTRODUCTION}

Nitric oxide (NO) and nitrogen dioxide $\left(\mathrm{NO}_{2}\right)$ play key roles in regulating atmospheric concentrations of ozone $\left(\mathrm{O}_{3}\right)$ and hydroxyl radical $(\mathrm{OH})$, the principal agents for atmospheric oxidation of a large number of compounds [Levy, 1972; Crutzen, 1979; Logan et al., 1981; World Meteorological Organization, 1985], and are precursors of nitric acid, a major component of acid deposition [Galloway and Likens, 1981].

There are few measurements of the flux of $\mathrm{NO}_{2}$ (NO and $\mathrm{NO}_{2}$ ) from soils, confined largely to temperate and subtropical regions (for review, see Galbally [1985]). Using existing data on $\mathrm{NO}_{x}$ fluxes from soils in temperate areas, Logan [1983] estimated that soils contribute approximately $15 \%$ of the global $\mathrm{NO}_{x}$ source. Two studies indicating large fluxes of NO from tropical forest soils have since been published. Delmas and Servant [1987] reported a mean NO flux of about $9.0 \times 10^{10}$ molecules $\mathrm{cm}^{-2} \mathrm{~s}^{-1}$ from the soil of a primary tropical moist forest in the Ivory Coast on two days during the dry season. During ABLE 2A Kaplan et al. [1988] measured an average NO flux of $5.2( \pm 1.7) \times 10^{10}$ molecules $\mathrm{cm}^{-2} \mathrm{~s}^{-1}$ from an undisturbed tropical forest soil in Brazil. These fluxes are 2-30 times larger than reported for vegetated, unfertilized soils in other climatic zones [Galbally and Roy, 1978; Johansson and Granat, 1984; Slemr and Seiler, 1984; Anderson and Levine, 1987; Williams et al., 1987]. Johansson et al. [1988] reported much lower NO fluxes from soils of a tropical cloud forest in Venezuela, where dry season emission rates ranged from $<0.9$ to $8.6 \times 10^{9}$ molecules $\mathrm{cm}^{-2} \mathrm{~s}^{-1}$.

Emissions of NO in tropical areas could be especially important to atmospheric chemistry. Photochemical reactions proceed most

\footnotetext{
${ }^{1}$ Division of Applied Sciences, Harvard University, Cambridge, Massachusetts.

2 Department of Geology, Princeton University, Princeton, New Jersey.

${ }^{3}$ Lamont-Doherty Geophysical Observatory, Palisades, New York.

4 Departmento Engenharea Agricola, Vicosa, Minas Gerais, Brazil.
}

Copyright 1990 by the American Geophysical Union.

Paper number $90 J \mathrm{JD} 00410$.

0148-0227/90/90JD-00410\$05.00 efficiently at low latitudes, due to greater solar UV flux and high atmospheric $\mathrm{H}_{2} \mathrm{O}$ content. Ecosystems in the humid tropics are characterized by rapid biological processes and high productivity leading to the emission to the atmosphere of many photochemically active trace gases [e.g., Crutzen et al., 1985; Harriss et al., 1988; Harriss et al., this issue]. Since tropical areas are being developed for human use at an accelerating rate, it is important to acquire data on the undisturbed system to allow quantification of potential impacts on the atmosphere [Fearnside, 1982; Crutzen, 1985; McElroy and Wofsy, 1986].

The data of Delmas and Servant [1987] and Kaplan et al. [1988] indicate the potential importance of tropical forest soils as a source for $\mathrm{NO}_{x}$. However, the measurements represent limited spatial and temporal scales $\left(\approx 10^{4} \mathrm{~m}^{2}\right.$ and 1 month during the dry season, respectively, for the Kaplan et al., [1988] study) Monthly rainfall may vary by a factor of 5 or more in the central Amazon Basin between the wet and dry seasons [Franken and Leopoldo, 1984]. Soil characteristics such as texture, moisture regime and nutrient availability vary markedly within tropical forest regions [e.g., Stark, 1971; Jordan et al., 1982; Vitousek and Sanford, 1986; Goreau and deMello, 1985] and may affect $\mathrm{NO}_{x}$ emissions [Slemr and Seiler 1984; Johansson and Granat, 1984; Williams et al., 1987; Anderson and Levine, 1987]. Previous studies did not examine the fate of nitrogen oxides after emission from the soil; a significant fraction of $\mathrm{NO}_{x}$ from soils may not escape from the forest canopy. Quantification of the atmospheric effects of soil emissions requires knowledge of the chemical and physical processes that affect these gases within the forest canopy.

This paper reports measurements of NO emissions from tropical forest soils in Brazil during the NASA/Instituto de Pesquisas Espaciais Amazon Boundary Layer Experiment (ABLE 2B), using chamber and vertical profile (chemical mass balance) methods, and examines atmosphere/biosphere exchange of nitrogen oxides in the forest canopy. Wet season conditions prevailed during the measurement period (April-May, 1987) and the data show generally lower fluxes than found by Kaplan et al. [1988] during the dry season for similar soils at a nearby site. An experiment in which plots were amended with various fertilizers $\left(\mathrm{NaNO}_{3}\right.$, $\mathrm{NH}_{4} \mathrm{Cl}$, and sucrose) indicated that reduction of oxidized precursors such as $\mathrm{NO}_{3}^{-}$(denitrification) may have been primarily 
responsible for soil NO emissions at this site, as was also found during the dry season [Kaplan et al., 1988]. Data for NO fluxes and concentrations are combined with measurements of total reactive nitrogen oxides $\left(\mathrm{NO}_{\mathrm{y}}\right)$ in a companion paper [Bakwin et al., this issue] to show that the forest canopy is a net sink for $\mathrm{NO}_{\mathrm{y}}$ during the wet season despite the proximate source of NO from the soil. Forest vegetation helps to maintain low ambient concentrations of $\mathrm{NO}_{x}$ and $\mathrm{NO}_{y}$, and thus plays an important role in regional photochemistry [Jacob and Wofsy, this issue].

\section{STUDY AREA}

The measurements were carried out at the Ducke Forest Reserve, $40 \mathrm{~km}$ North of Manaus, Brazil, between Apil 15 and May 10,1987. The site was occupied by terra firma forest with an average canopy height of about $30 \mathrm{~m}$, with emergents to $35 \mathrm{~m}$. Measurements of profiles for atmospheric $\mathrm{NO}$ and $\mathrm{O}_{3}$ were carried out using a $43 \mathrm{~m}$ high tower located on top of a small hill. Chamber measurements of NO fluxes were made at several sites on the clay-textured soil (yellow Oxisol) near the tower (sites A, $F$, and $T$ ) and on the hill slope $=750 \mathrm{~m}$ from the tower (site $B$ ), and on the sandy soil of the campina about $1500 \mathrm{~m}$ west of the tower near the base of the hill (site $C$ ). The sandy soil was covered by a dense root mat. The clay soil is the dominant soil type in the area [Food and Agriculture Organization, (FAO), 1971; Vitousek and Sanford, 1986]. More detailed site descriptions can be found in papers by Stark, [1971], Roberts et al. [1990], Keller et al. [1988], and Livingston et al. [1988].

\section{EXPERIMENTAL METHODS}

\subsection{Chamber Measurements}

One week or more prior to the initiation of flux measurements small square (10 x $10 \mathrm{~cm}$ and $15.3 \mathrm{~cm}$ high) and larger round (24.8 $\mathrm{cm}$ diameter and $16.4 \mathrm{~cm}$ high) collars were driven about 5 $\mathrm{cm}$ into the ground at each study site. A flux measurement was made by placing a fitted top on a collar and sampling the head space continuously for about $10 \mathrm{~min}$, with a sample flow rate of $200-300 \mathrm{~cm}^{3} / \mathrm{min}$ STP. Square tops were $15.3 \mathrm{~cm}$ high, the round collars were fitted with either a flat top or a $19.0 \mathrm{~cm}$ high top. Tops and collars were made of aluminum coated with FEP Teflon. A $1.5 \mathrm{~cm}$ diameter hole in each top served as an air inlet and a 4 mm ID Teflon outlet tube ran from the chamber to the NO analyzer (Figure 1). Mixing of the chamber air was accomplished using an aluminum impeller driven at $120 \mathrm{rpm}$ by a battery operated motor mounted outside the chamber. Nitric oxide flux was calculated from the initial rate of concentration increase in the chamber. There was no evidence of any systematic differences between fluxes measured using the large round or small square chambers. Systematic variation of sample flow rate established

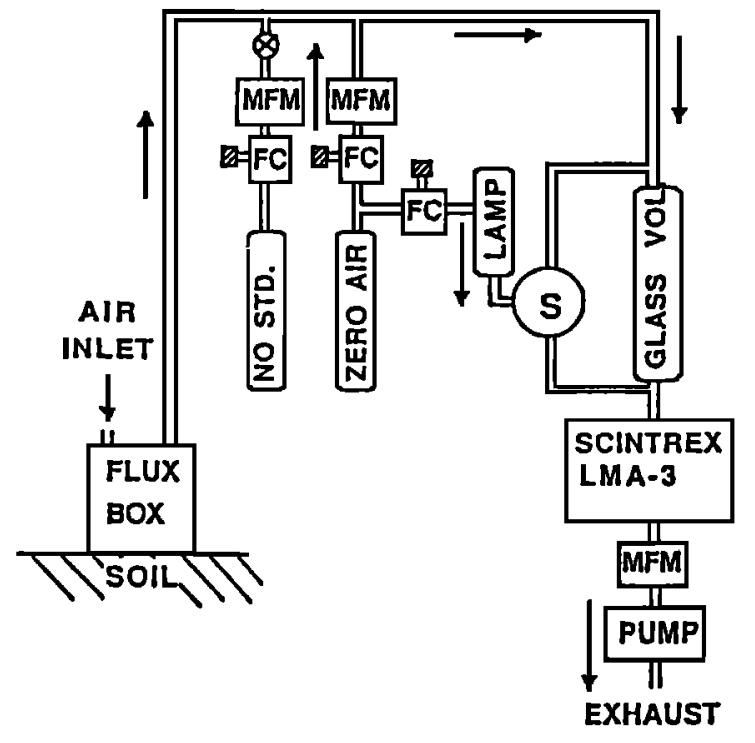

Fig. 1. Experimental design for the chamber measurements of NO flux. FC, flow control valve; MFM, mass flow meter [MKS Instruments, Inc.], $S$, three-way valve.

that flux values were independent of flow rate for the values adopted here.

Sites were selected to give maximum information about the spatial and temporal variability of NO fluxes while simultaneously allowing a time-resolved fertilization experiment to be carried out. In most cases, $3 \times 6 \mathrm{~m}$ plots were equally divided into eight sectors. Within each of six randomly selected sectors a collar was emplaced, using five small square collars and one large round collar. One to four plots were located within about $20 \mathrm{~m}$ of each other at several sites on the clay and sandy soils (Table 1). For the fertilization experiments individual subplots within some of the plots were treated with $\mathrm{NaNO}_{3}, \mathrm{NH}_{4} \mathrm{Cl}\left(50 \mathrm{~kg} \mathrm{~N} \mathrm{ha}^{-1}\right)$ or sucrose $\left(500 \mathrm{~kg} \mathrm{C} \mathrm{ha}^{-1}\right)$ dissolved in $1 \mathrm{~L}$ of distilled water. Distilled water was added to control plots. Flux measurements were made 0.5 , 2.5 , and 4.5 hours after application of the fertilizer and then at various intervals on subsequent days.

Chamber air was analyzed for NO concentration using a Scintrex LMA-3 luminol-based $\mathrm{NO}_{2}$ analyzer modified for $\mathrm{NO}$ analysis as described by Bakwin et al. [this issue]. Conversion of $\mathrm{NO}$ to $\mathrm{NO}_{2}$ was accomplished by reaction with about $500 \mathrm{ppbv} \mathrm{O}_{3}$ in a $300 \mathrm{~cm}^{3}$ glass volume just upstream of the detector (Figure 1). Ozone was generated using a "Pen-ray" type $\mathrm{Hg}$ vapor lamp (UVP, San Gabriel, Califomia) to irradiate a stream of "zero" air flowing at $30 \mathrm{~cm}^{3} / \mathrm{min}$ STP. The instrument was zeroed between each flux measurement by switching the $\mathrm{O}_{3}$ addition point to downstream of the reaction volume. In this configuration NO was

TABLE 1. Field Sites for NO Flux Measurements by the Chamber Method Including Fertilizer Treatments at Each Site

\begin{tabular}{|c|c|c|c|}
\hline Site & $\begin{array}{l}\text { Number } \\
\text { of Plots }\end{array}$ & $\begin{array}{c}\text { Total Number } \\
\text { of Collars }\end{array}$ & $\begin{array}{c}\text { Fertilizations } \\
\text { (Plot No. Treatments) }\end{array}$ \\
\hline$\overline{A \text { (clay) }}$ & 4 & 24 & $\begin{array}{l}\text { A-I: } \mathrm{NO}_{3}^{-}, \mathrm{NH}_{4}^{+}, \text {sucrose } \\
\text { A-I: } \mathrm{NO}_{3}^{-}, \text {sucrose }\end{array}$ \\
\hline B (clay) & 2 & 12 & none \\
\hline$F$ (clay) & & 8 & none \\
\hline $\mathrm{T}$ (clay) & 1 & 8 & none \\
\hline$C$ (sand) & 3 & 18 & $\begin{array}{l}\text { C-I: } \mathrm{NO}_{3}^{-}, \mathrm{NH}_{4}^{+}, \text {sucrose } \\
\text { C-II: } \mathrm{NO}_{3}^{-}, \mathrm{NH}_{4}^{+}, \text {sucrose }\end{array}$ \\
\hline
\end{tabular}


not oxidized to $\mathrm{NO}_{2}$ but the background signal due to $\mathrm{O}_{3}$ remained constant. The total flow rate through the instrument was about $1000 \mathrm{~cm}^{3} / \mathrm{min}$ STP. It was necessary to keep the air flow through the chamber to a minimum in order to avoid disturbing the soil air and thereby possibly inducing NO emission [Kaplan et al., 1988]. Therefore $700-800 \mathrm{~cm}^{3} / \mathrm{min}$ STP of "zero" air was added to $200-300 \mathrm{~cm}^{3} / \mathrm{min}$ STP of air drawn from the chamber. Calibration was by standard addition of a small flow of NO standard ( 1 ppmv NO in $\mathrm{N}_{2}$ ) to sample air. Flows were measured using MKS mass flow meters (MKS Instruments, Inc., Burlington, Massachusetts) powered by lead-acid batteries.

Interferences to the LMA-3 NO analysis include $\mathrm{NO}_{2}, \mathrm{O}_{3}$, and peroxyacetylnitrate (PAN). None of these species are expected to be produced by the soils studied, and ambient levels of these reactive species were expected to rapidly decline to zero in the enclosure [Anderson and Levine, 1987]. A buildup of any of these species in the flux box would have been observed as an increase in the instrument signal in the zeroing mode, when NO was not being detected. No such drift of the zero level was seen. Flux measurements using the modified LMA-3 were checked against measurements using a TECO-14A $\mathrm{O}_{3}$-chemiluminescence NO detector (Thermo Environmental, Hopkinton, Massachusetts) in the lab and field, with excellent results, confirming that these soils do not emit significant levels of interfering species. The LMA-3 has the advantage of being portable and requiring low power. Further, the LMA-3 features a fast response and high sensitivity, allowing NO fluxes to be calculated from the first few minutes of data following enclosure. The minimum detectable flux was about $1 \times 10^{9}$ molecules $\mathrm{cm}^{-2} \mathrm{~s}^{-1}$ for a $10 \mathrm{~min}$. experiment.

\subsection{Profile Measurements}

Profile measurements of $\mathrm{NO}$ and $\mathrm{O}_{3}$ were obtained through the forest canopy at eight heights, $0.02,3,6,12,19,27,36$, and $41 \mathrm{~m}$. The NO concentrations were determined using a TECO-14A $\mathrm{O}_{3}$ chemiluminescence detector modified to increase sensitivity and stability (detection limit 40 pptv (parts per trillion by volume), for 2-min average). Ozone was measured using a Dasibi 1003-AH UV photometer and by a chemiluminescence instrument using $\mathrm{C}_{2} \mathrm{H}_{4}$ (Monitor Labs, model 8410). Experimental details are given by Bakwin et al. [this issue]. An estimate for the NO flux was obtained from nighttime profiles of $\mathrm{NO}$ and $\mathrm{O}_{3}$ [Parrish et al., 1987; Kaplan et al., 1988]. The one-dimensional mass balance equation for NO in a layer of thickness $h$ is

$$
\frac{\partial}{\partial t}\left(\int_{0}^{h}[\mathrm{NO}] d z\right)+F_{h}-F_{\mathrm{o}}=\int_{0}^{h}(P-L) d z
$$

where $F_{h}$ and $F_{o}$ are the NO fluxes across the upper boundary and the soil-air interface respectively, $P$ and $L$ are the chemical production and loss rates for NO within the layer, $z$ is height, and $t$ is time. At night $P \approx 0$ (i.e., no NO production by photolysis of $\mathrm{NO}_{2}$ ). Reaction with $\mathrm{O}_{3}$ should be the dominant sink for NO so that (1) reduces to

$$
F_{\mathrm{o}}-F_{h}=\partial / \partial t\left(\int_{0}^{h}[\mathrm{NO}] d z\right)+\int_{0}^{h} k[\mathrm{NO}]\left[\mathrm{O}_{3}\right] d z
$$

where $k$ is the rate constant for reaction of $\mathrm{NO}$ with $\mathrm{O}_{3}$. If the concentration of NO above height $h(41 \mathrm{~m})$ is sufficiently small, then $F_{h}$ may be neglected and (2) gives the NO emission rate from the soil averaged over an area which influences the NO profile $\left(\approx 10^{4} \mathrm{~m}^{2}\right)$.
Equation (2) represents the NO soil flux as a balance between the total amount of NO stored in the canopy layer and the homogeneous loss of $\mathrm{NO}$ by reaction with $\mathrm{O}_{3}$, the first and second terms on the right-hand side of (2) respectively. Both terms on the right hand side of (2) may be determined from the profile measurements, allowing calculation of $F_{0}-F_{h}$. The result represents a lower limit of the soil flux, $F_{\mathrm{o}}$ : other chemical processes (e.g., deposition on leaves, oxidation by organic peroxy radicals) may remove NO, also $F_{h}$ may not be negligible.

\section{Results}

\subsection{Chamber Measurements on Unfertilized Plots}

Figure 2 presents approximate probability distribution functions [see Keller et al., 1983] for NO flux measurements from unfertilized collars on the clay and sandy soils. The points represent daily means of measurements from a particular collar. Data from the same collar taken on different days are considered independent. An exception was made for site $F$, which was sampled intensively for 3 days: only the overall mean for each collar was used to avoid giving undue weight to this site. The 116 points on these plots represent a total of 224 individual flux measurements from 66 different collars (49 on clay soil and 17 on sandy soil). The distributions in Figure 2 are strongly non-Gaussian (normal distributions would be represented by a straight line on these plots). There are a small number of measurements with flux values much higher than the median, a distribution similar to those found by Keller et al. $[1983,1986]$ for $\mathrm{N}_{2} \mathrm{O}$ emissions from soils in similar environments.

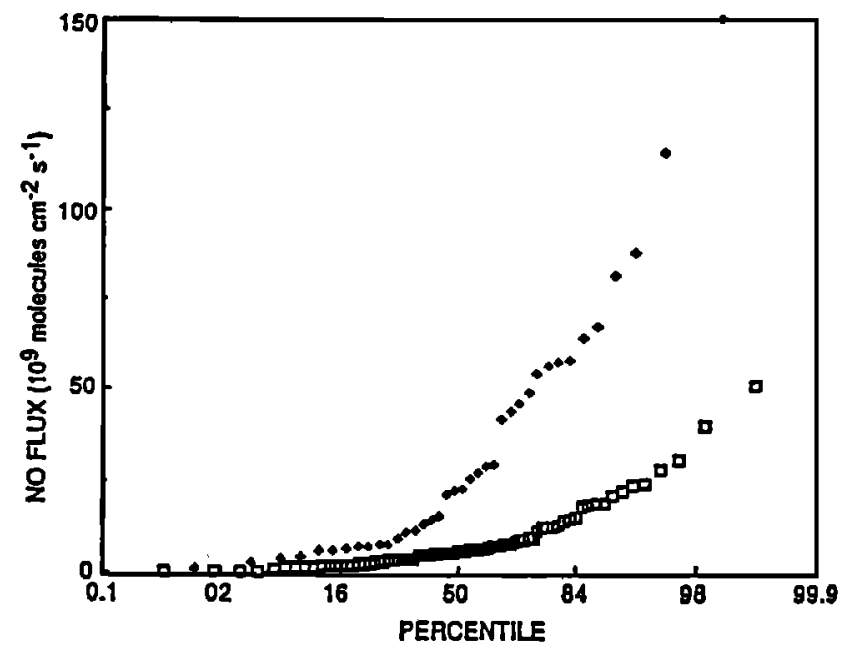

Fig. 2. Approximate probability distribution functions of NO flux measurements by the chamber method. The flux is plotted against the estimated probability $\left[P_{i}=[i-1 / 2] / N\right]$ of finding a flux smaller than the flux $F_{i}$ where $i$ is the rank in the set of observations of number $N$. Points represent daily means of multiply sampled collars [see text]. Open squares indicate data from clay soil sites, solid diamonds show sandy soil sites.

The mean NO fluxes for the clay and sandy soils ( $\pm 95 \%$ confidence interval calculated by the "bootstrap method" of Efron and Tibshirani [1986]) were $8.9( \pm 1.5, n=78) \times 10^{9}$ molecules $\mathrm{cm}^{-2} \mathrm{~s}^{-1}$ and $33.8( \pm 6.5, n=38) \times 10^{9}$ molecules $\mathrm{cm}^{-2} \mathrm{~s}^{-1}$, respectively. Mean values are insensitive to the treatment of multiply sampled plots: nearly identical results are obtained if multiple samples from the same collar are considered independent or if daily means 
are used. The standard deviations were $8.0 \times 10^{9}$ molecules $\mathrm{cm}^{-2} \mathrm{~s}^{-1}$ and $24.4 \times 10^{9}$ molecules $\mathrm{cm}^{-2} \mathrm{~s}^{-1}$, respectively. The large coefficients of variation indicate substantial temporal and spatial variability.

Figures $3 a$ and $b$ show time courses of NO flux from particular collars on clay and sandy soils, respectively, and Figure $3 c$ shows a time history of rainfall amount at the tower (L. Molion, unpublished data, 1988). Fluxes at site A (Figure 3a) display no apparent relationship to rainfall, but are characterized by large transient variations. The data from site $\mathrm{C}$ (Figure $3 b$ ) appear to show an effect of rain. Small fluxes were measured at this site during an initial wet period. Fluxes from each collar were highest following a dry period which lasted at least 2 days, and then declined gradually with subsequent rainfall.

Most of the flux measurements reported here were made during the daylight hours. To investigate the possibility of a diel variation in NO flux site F was established near the base of the tower and sampled intensively from the evening of May 7 to the night of May 9, 1987. No rainfall occurred during this interval. The
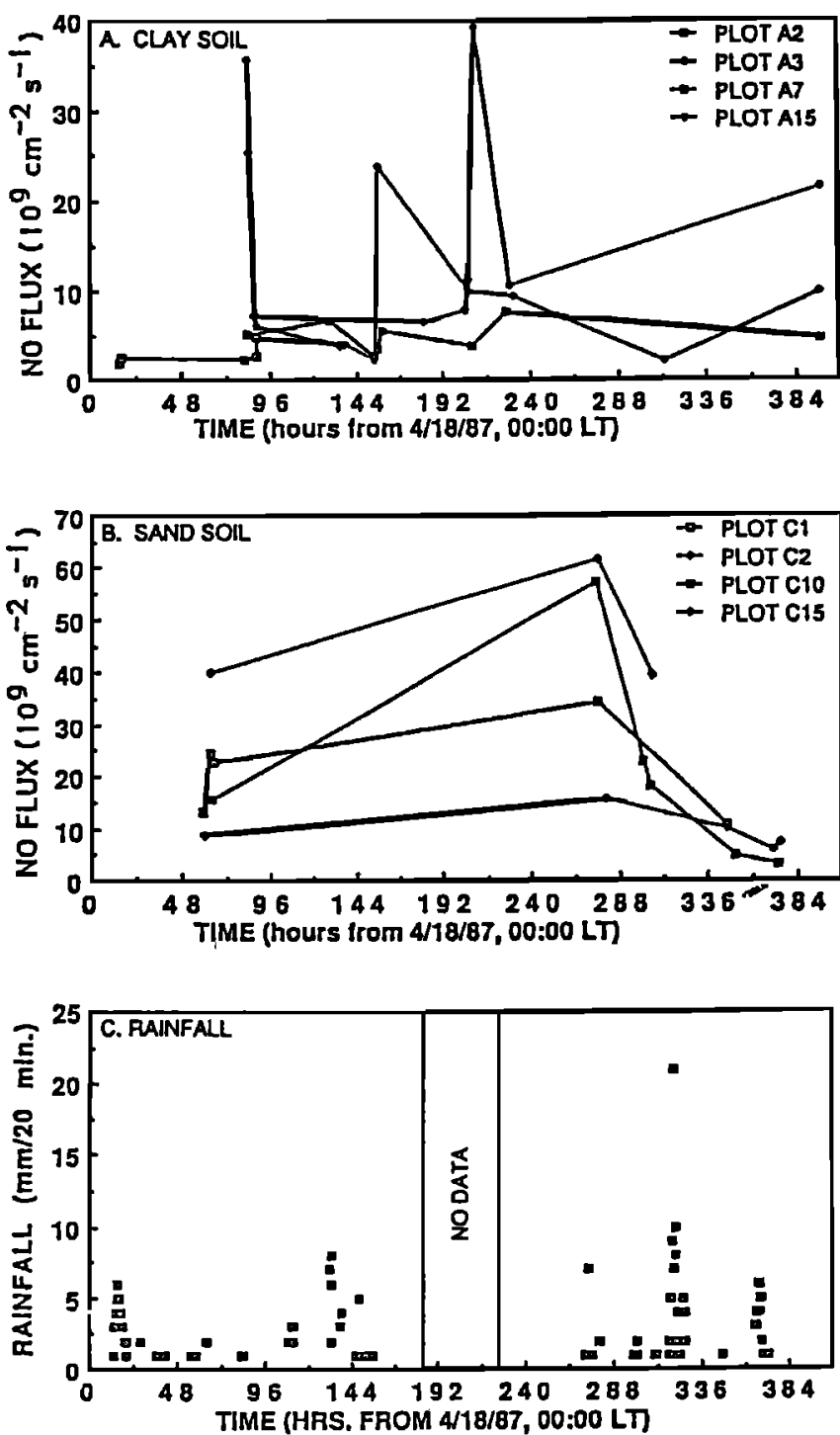

Fig. 3. Nitric oxide flux or rainfall rate versus time: (a) clay soil, (b) sandy soil, (c) rainfall rate (L. Molion, unpublished data, 1988). Rainfall data are missing for the period indicated and for the aftemoon of April 21, on which there was a heavy thunderstorm. results, presented in Figure 4, show no clear diel pattern. This is as might be expected considering that the soil surface temperature at this site was virtually constant at $25-26^{\circ} \mathrm{C}$ (S. Trumbore, unpublished data, 1988) and studies in temperate areas have found that diel trends in NO emissions are controlled primarily by temperature [Slemr and Seiler, 1984; Johansson and Granat, 1984; Anderson and Levine, 1987; Williams et al., 1987].

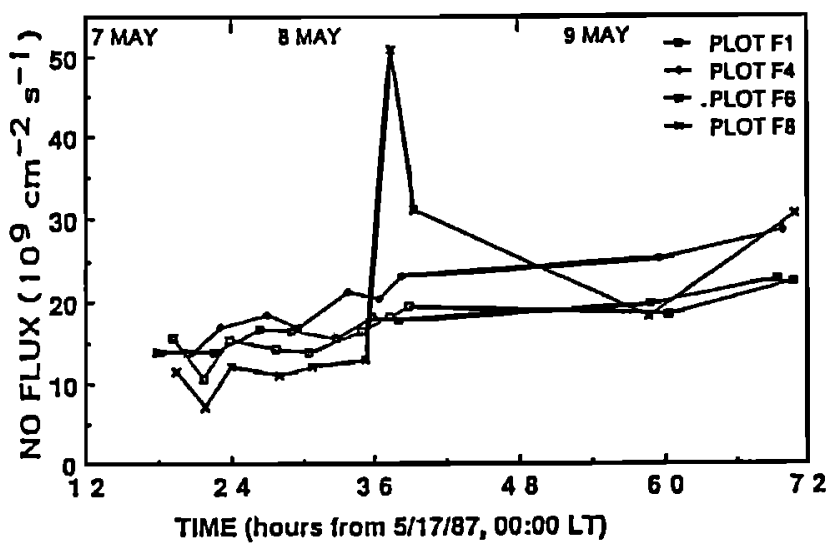

Fig. 4. Results of a diumal study of NO emissions from clay soil (May 7 $9,1987)$. Results from each collar are plotted separately, only four of the eight collars sampled are shown.

An interesting feature of the data in Figure 4 is the spike in the NO flux observed from collar F8 at 13:30 on May 8, 1987. The NO flux increased at that site by a factor of 4 in just over 2 hours. The flux determination at 15:15 confirmed the increase, although by that time the flux had decreased to about $60 \%$ of the maximum. Similar short term transient increases are typical of NO emissions from other collars on the clay soil but were not observed on the sandy soil (Figure 3).

The mean ( $\pm 95 \%$ confidence interval) of the NO fluxes at site $F$ was $21.0( \pm 1.9, n=80) \times 10^{9}$ molecules $\mathrm{cm}^{-2} \mathrm{~s}^{-1}$, more than a factor of 2 higher than the mean for the other clay soil sites. High values at site $F$ could reflect natural spatial variation or could result from disturbance in the vicinity of the tower. The area immediately surrounding the collars had been cordoned off approximately 1 month prior to the initiation of these measurements, however the tower has seen frequent use since it was erected in 1983 [e.g., Shuttleworth et al., 1984; Roberts et al., 1990]. These data were included in the overall mean NO flux reported above; the result would have been smaller by about $20 \%$ if these data were omitted.

\subsection{Fertilization Experiments}

In all four fertilization experiments the addition of $\mathrm{NO}_{3}^{-}$caused a large and immediate increase in the NO flux (Figure 5). Increases of five-fold to 150 -fold were measured just $30 \mathrm{~min}$. after application of the fertilizer, and the maximum response was always seen at this earliest time point. Other fertilized plots and control plots showed no pronounced increase in NO flux, except for one $\mathrm{NH}_{4}^{+}$fertilized plot at site $\mathrm{C}$ which showed a response similar to that of the $\mathrm{NO}_{3}^{-}$fertilized plots.

\subsection{Nocturnal Vertical Profiles}

Simultaneous vertical profiles of $\mathrm{NO}$ and $\mathrm{O}_{3}$ concentrations through the forest canopy were obtained on eight nights in late 

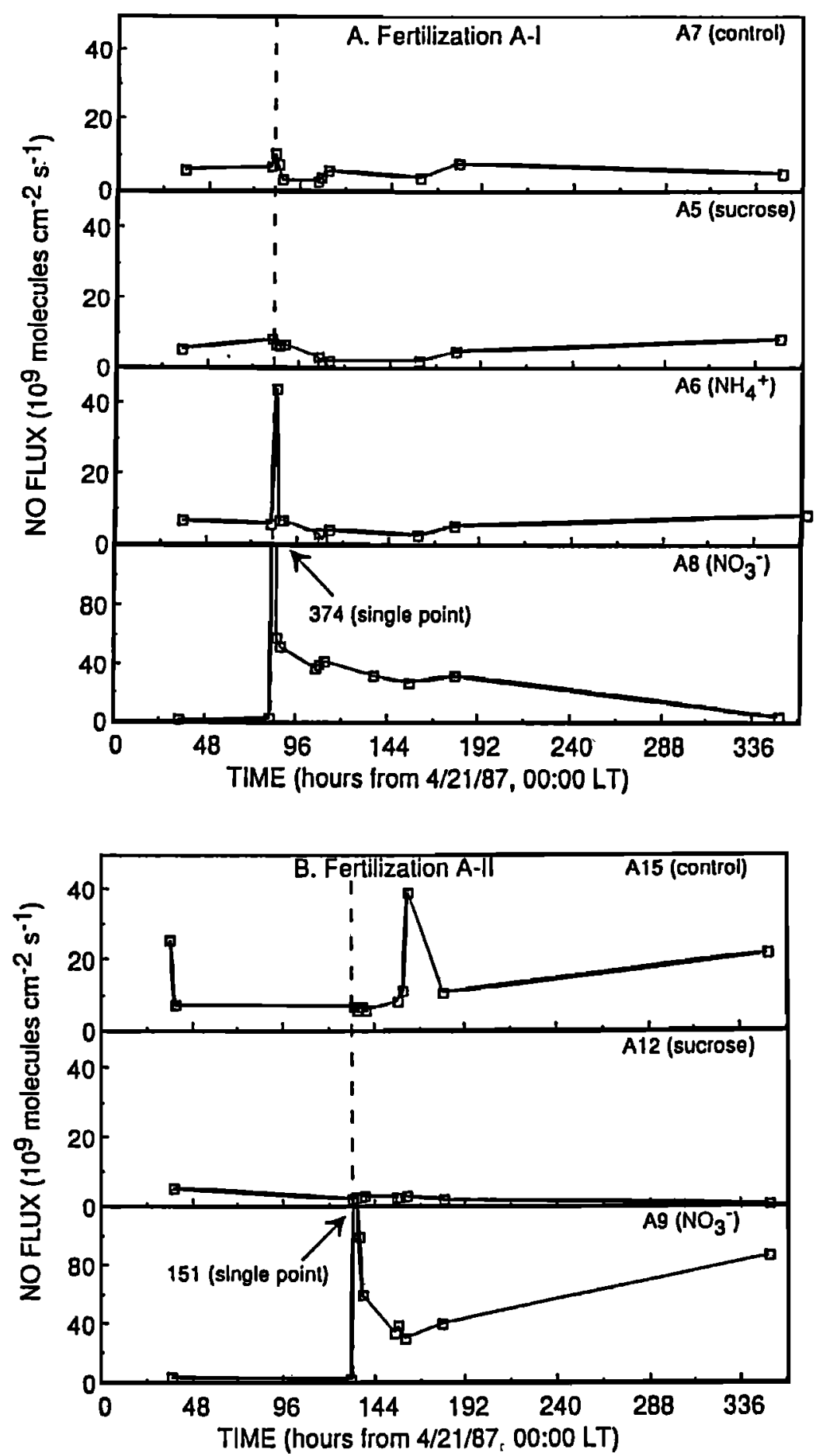

Fig. 5. Results of the fertilization experiments summarized in Table 1: (a) A-I, (b) A-II, (c) C-I, and (d) C-II. Symbols correspond to fertilizer treatments as indicated. Dashed line indicates time of fertilizer application.

April and early May 1987. Examples of observed profiles are shown in Figure 6. Ozone concentrations were very low, generally only 3-6 ppbv (parts per billion by volume) above the canopy, and concentrations decreased sharply in descent through the canopy, to near zero ppbv at the ground. High concentrations of NO were observed near the ground, reflecting the soil source. Concentrations of NO near the detection limit of the TECO-14A (about 40 pptv for a $2-\mathrm{min}$ average) were usually observed at the top of the tower. The volumetric loss rate of NO was on average nearly uniform with height from $10 \mathrm{~m}$ to the top of the tower, about $1 \times 10^{5}$ molecules $\mathrm{cm}^{-3} \mathrm{~s}^{-1}$

Figure 7 shows values for individual terms in (2) calculated from data for the nights of April 22, 23, and 24, 1987. The chemical loss term usually dominated and was not correlated with the storage term. Occasionally the storage term became dominant, as was observed between about 2100 on April 22 and 0030 on April 23. when two events occurred which abruptly removed NO from the canopy. The large negative values of the storage term in Fig- 

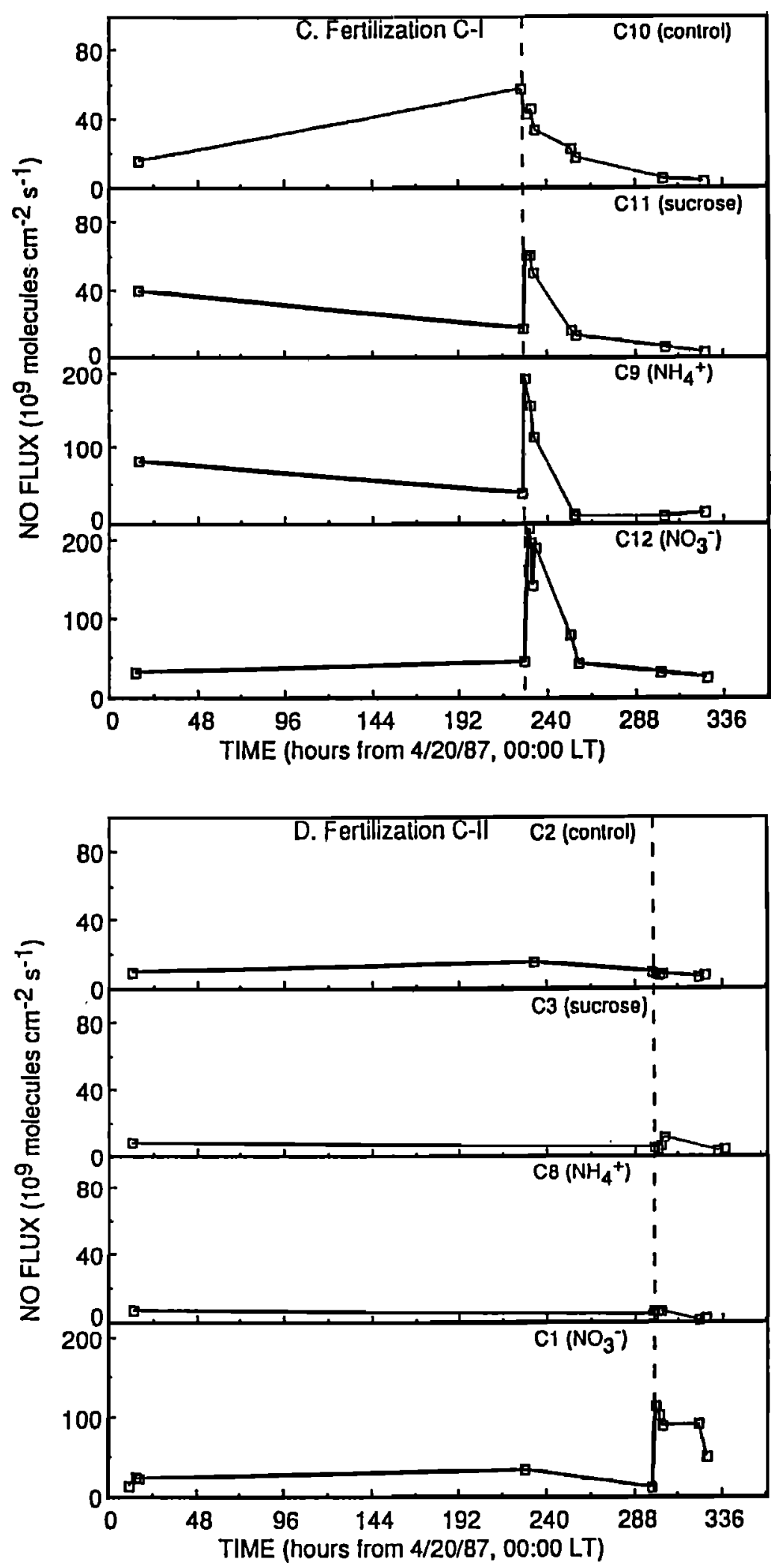

Fig. 5. (continued)

ure $7 a$ reflect these events. These events most likely represent instances of intrusion of low-NO air into the canopy from above [see Fitzjarrald et al., this issue]. Despite such events, on average the amount of NO within the canopy changed little during the night, so the mean of the storage term was generally small. For all eight nights the mean value for $F_{0}-F_{k}( \pm 95 \%$ confidence inter- val) calculated using (2) was $5.1( \pm 0.9, n=108) \times 10^{9}$ molecules $\mathrm{cm}^{-2} \mathrm{~s}^{-1}$. The mean for the chemical loss term alone was 4.6 $( \pm 0.6) \times 10^{9}$ molecules $\mathrm{cm}^{-2} \mathrm{~s}^{-1}$. Hence inclusion of the storage term changed the mean calculated NO soil flux by only about $10 \%$. The differencing required to compute the storage term increased the variance somewhat. Because of the extremely low $\mathrm{O}_{3}$ 

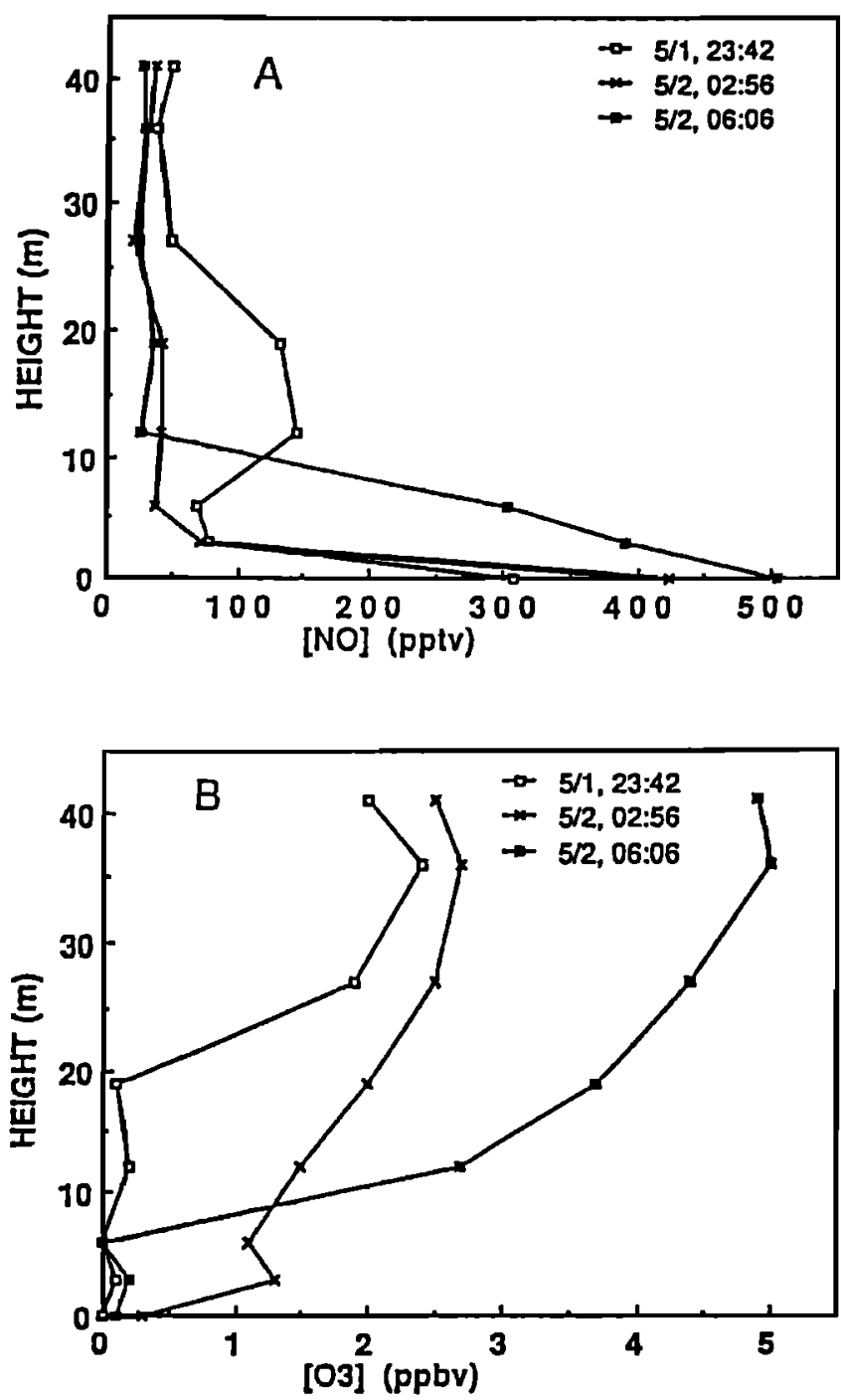

Fig. 6. Example nighttime profiles of (a) NO and (b) $\mathrm{O}_{3}$.

concentrations within the canopy at night ( $<3 \mathrm{ppbv}$, Figure $6 b)$ the observed column loss of $\mathrm{NO}$ by reaction with $\mathrm{O}_{3}$ is sensitive to uncertainties introduced by the resolution of the instrument used to measure $\mathrm{O}_{3}( \pm 0.5 \mathrm{ppbv}$ for a 3-min average).

\section{Discussion}

Fluxes of NO measured from the clay soils averaged $8.9( \pm 1.5)$ x $10^{9}$ molecules $\mathrm{cm}^{-2} \mathrm{~s}^{-1}$, about a factor of 6 lower than that found by Kaplan et al. [1988] on clay soils at a nearby site during the dry season of 1985 . Rain events had no discernible effect on emissions from the clay soils. The NO emission rate from sandy soil was higher than from clay soils by nearly a factor of 4 , and varied inversely with rainfall amount (Figure 3). Roberts et al. [1990] found that the matric potential of the $0-30 \mathrm{~cm}$ depth interval of clay soil at this site was small and relatively constant during the wet season (March-April) of 1985, although daily rainfall amount varied widely, indicating that this soil remains near saturation during much of the wet season. Dry season measurements showed generally larger and much more variable matric potential. It is therefore not suprizing that NO fluxes from the clay soil do not respond to rain events.

Rapid temporal variations were characteristic of NO fluxes from clay (see Figures 3a and 4) but not the sandy soil, possibly reflecting subtle differences in microenvironment. Short term changes suggest that either the source of NO, or a strong sink for NO, was in the soil zone nearest the surface, since it is this zone that is most subject to the influence of varying environmental conditions.

The higher NO flux from sandy soil contrasted with the trend observed for $\mathrm{N}_{2} \mathrm{O}$ flux by Matson et al. [this issue] who sampled in parallel with some of the measurements discussed here. Similarly, Goreau and de Mello [1985] found that $\mathrm{N}_{2} \mathrm{O}$ fluxes from clay soils at Ducke Forest Reserve were nearly a factor of 3 higher than from sandy soils in the dry season. These comparisons indicate differences in processes that control the production and/or escape of $\mathrm{NO}$ and $\mathrm{N}_{2} \mathrm{O}$ from these soils. Escape efficiency is probably much more important in regulating $\mathrm{NO}$ than $\mathrm{N}_{2} \mathrm{O}$ flux due to the greater chemical reactivity of NO, so that the higher NO fluxes on the porous sandy soil could simply reflect better ventilation, even if the in situ production rate was lower. In support of this idea the ${ }^{222} \mathrm{Rn}$ study of Trumbore et al. [1990] showed that, during the period of our measurements, the gas exchange rate between the soil air space and the atmosphere (expressed as a bulk
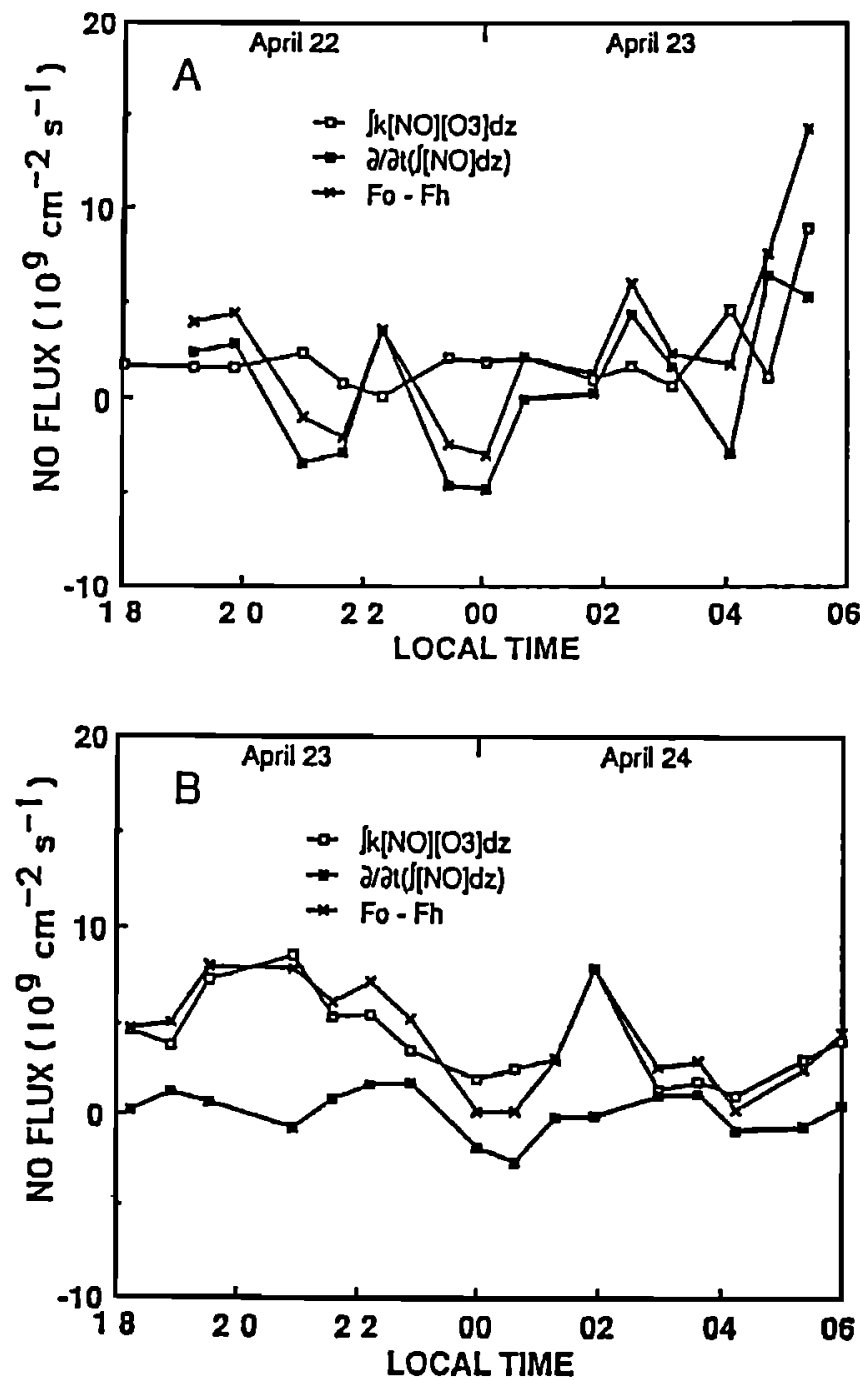

Fig. 7. Examples of terms in (2) for the nights of April 22, 23, and 24, 1987. Each point represents a single profile. Open squares $=$ $\int_{0} k[\mathrm{NO}]\left[\mathrm{O}_{3}\right] d z$, solid squares $=\partial / \partial t\left(\int[\mathrm{NO}] d z\right)$, and crosses $=F_{0}-F_{h}$. 
diffusivity) was about 4 times larger for the sandy soil than for the clay soil.

The seasonal variation of $\mathrm{NO}$ and $\mathrm{N}_{2} \mathrm{O}$ emissions suggests that NO efflux from soils may be strongly modulated by physical processes controlling air exchange between the soil and atmosphere. The most important parameter for controlling the soilatmosphere air exchange is probably the amount of connected airfilled pore space in the soil. Drier and coarser textured soils tend to be better ventilated and thus allow more NO to escape.

Fertilizer experiments provide additional information on processes that control NO production in these soils. Nitrate additions caused a large and immediate increase in the NO flux while sucrose additions did not. Only one out of the three of plots amended with $\mathrm{NH}_{4}^{+}$showed an increased NO flux following fertilization. Addition of $\mathrm{NO}_{3}^{-}$stimulated large enhancements of $\mathrm{NO}$ emissions from soils at a nearby site during the dry season [ $\mathrm{Ka}$ plan et al., 1988]. Laboratory studies show that $\mathrm{NO}$ and $\mathrm{N}_{2} \mathrm{O}$ may be produced biologically by both denitrification [Payne, 1982; Anderson and Levine, 1986] and nitrification [Goreau et al., 1980; Lipschultz et al., 1981; Anderson and Levine, 1986], and abiologically by the decomposition of $\mathrm{NO}_{2}^{-}$[Nelson and Bremner, 1970]. Both gases may be used as a substrate during denitrification [Payne, 1981]. Our results for the $\mathrm{NO}_{3}^{-}$and sucrose additions indicate that a reductive process (i.e., denitrification) was primarily responsible for production of the NO released by both soils studied and that this process was nitrogen limited, but not carbon limited. If $\mathrm{NO}_{2}^{-}$decomposition was the source of the $\mathrm{NO}$ produced from added $\mathrm{NO}_{3}^{-}$it must have followed biological reduction of $\mathrm{NO}_{3}^{-}$to $\mathrm{NO}_{2}^{-}$. It is not clear whether oxidative processes (e.g., nitrification) play a role. An increase in the input of $\mathrm{NO}_{3}^{-}$by dry or wet deposition, due to increased biomass or fossil fuel burning, could result in enhancement of the NO flux from these soils.

The mean flux $\left(F_{0}-F_{h}\right)$ calculated from noctumal $\mathrm{NO}$ and $\mathrm{O}_{3}$ concentrations was $5.1( \pm 0.9) \times 10^{9}$ molecules $\mathrm{cm}^{-2} \mathrm{~s}^{-1}$, about $40 \%$ lower than the mean from chamber measurements. The profile method yields a lower limit to the soil emission rate if the upward NO flux through the top level $(41 \mathrm{~m}$ ) is not negligible (i.e., $F_{h}$ is not zero) or if processes other than oxidation by $\mathrm{O}_{3}$ remove NO within the canopy layer. Very low $\mathrm{O}_{3}$ concentrations prevailed during the measurement period, providing a favorable setting for both of these processes. The relatively large value for $F_{h}$ $\left(F_{h} / F_{o} \approx 0.4\right.$, where $F_{\mathrm{o}}$ is taken as the mean soil emission rate from the chamber measurements) appears to reflect the long lifetime for NO, which allows significant quantities of NO to rise above the canopy at night. Detailed model calculations by Jacob and Wofsy [this issue] indicate that, at night, $80-90 \%$ of the NO emitted from the soil is converted to $\mathrm{NO}_{2}$ by $\mathrm{O}_{3}$ and, to a lesser extent, by $\mathrm{HO}_{2}$ and organic peroxy radicals within the $0-41 \mathrm{~m}$ layer, a somewhat greater amount than indicated by the results presented here. Some of this $\mathrm{NO}_{2}$ may be deposited back onto the canopy. For the full diumal cycle the model indicates that the mean $\mathrm{NO}_{x}$ release to the atmosphere was only about $20 \%$ of the soil emission rate due to loss of $\mathrm{NO}_{2}$ to the canopy. However, the uncertainties in the measurements and the model preclude a definative assessment. The analysis does not allow for deposition of NO to leaves. Nitric oxide may have been deposited to, or catalytically oxidized on, leaf surfaces. The uptake of NO by various natural and man made surfaces has been documented [Hill, 1971; Judeikis and Wren, 1978; Johansson, 1987; Kisser-Priesack et al., 1987] but, to our knowledge, estimates of NO removal rates by leaf surfaces have not been made.

Escape of NO is likely to be more efficient in the day than at night since air exchange between the canopy and the mixed layer is much faster during the day [Fitzjarrald et al., this issue]. In order to determine overall impact of the forest on the reactive nitrogen oxide $\left(\mathrm{NO}_{y}\right)$ budget of the tropical atmosphere, including the fate of NO emitted from the soil, the study reported on by Bakwin et al. [this issue] was undertaken. The results of that study indicate that the forest was a net sink for $\mathrm{NO}_{y}$ during the wet season. The role of the forest as a sink for $\mathrm{NO}_{\mathrm{y}}$ is consistent with the observations of A. L. Torres and K. R. Hooks (unpublished manuscript, 1989) of NO levels in the mixed layer over Ducke and the surrounding area at or below the detection limit of their instrument ( $\approx 10$ pptv) except as could be attributed to pollution from the nearby city of Manaus. Conditions may have been quite different during the dry season when soil fluxes $\left(52.3( \pm 1.7) \times 10^{9}\right.$ molecules $\mathrm{cm}^{-2} \mathrm{~s}^{-1}$ ) [Kaplan et al., 1988] and atmospheric levels of NO (25-65 pptv) [Torres and Buchan, 1988] were much higher.

The data suggest that the forest plays a major role in regulating the abundance of $\mathrm{NO}_{x}$ and $\mathrm{NO}_{y}$ in the tropical atmosphere, and that the forest functions very differently in the wet season than in the dry season. During the wet season low soil emissions of NO, efficient conversion of $\mathrm{NO}$ to other $\mathrm{NO}_{y}$ species, and deposition back to the forest, result in low concentrations of $\mathrm{NO}$ and $\mathrm{NO}_{\mathrm{y}}$ in the lower atmosphere. These conditions should lead to slow or negative rates of photochemical oxidant formation [Crutzen, 1985; $J a c o b$ and Wofsy, this issue], consistent with the observation of low $\mathrm{O}_{3}$ concentrations and a persistent increase with height through the boundary layer of $\mathrm{O}_{3}$ concentration during the wet season [Fan et al., this issue; Browell et al., this issue; Gregory et $a l$. this issue; Kirchhoff et al., this issue].

Higher concentrations of NO during the dry season reflect larger soil sources and possibly inputs from biomass burning [Torres and Buchan, 1988]. Enhanced $\mathrm{NO}_{x}$ concentrations lead to photochemical production of $\mathrm{O}_{3}$ over the Amazon Forest [Crutzen et al., 1985; Jacob and Wofsy, 1988]. Modulations of oxidant concentrations in the tropical mixed layer by seasonally varying NO emissions from tropical forest soils and by uptake of reactive nitrogen oxides in the forest canopy may play an important role in global atmospheric chemistry and needs to be incorporated in global models.

Acknowledgements. We are indebied to A. Torres, G. Gregory, D. Jacob, and members of the ABLE2B science team for helpful discussions and sharing of data. This work was supported by NASA grant NAG-1-55 and NSF grant ATM.8413153 to Harvard University and by the Instituto de Pesquisas Espaciais [INPE].

\section{REFERENCES}

Anderson, I.C., and J.S. Levine, Relative rates of nitric oxide and nitrous oxide production by nitrifiers, denitrifiers, and nitrate respirers, Appl. Environ. Microbiol., 51, 938-945, 1986.

Anderson, I.C., and J.S. Levine, Simultaneous field measurements of biogenic emissions of nitric oxide and nitrous oxide, J. Geophys. Res., 92, 965-976, 1987.

Bakwin, P.S., S.C. Wofsy, and S.-M. Fan, Measurements of reactive nitrogen oxides $\mathrm{NO}_{y}$ within and above a tropical forest canopy in the wet season, J. Geophys. Res., this issue.

Browell, E.V., G.L. Gregory, R.C. Harriss, and V.W.J.H. Kirchhoff, Ozone and aerosol distributions over the Amazon Basin during the wet season, J. Geophys., Res., this issue.

Crutzen, P.J., The role of $\mathrm{NO}$ and $\mathrm{NO}_{2}$ in the chemistry of the troposphere and stratosphere, Annu. Rev. Earth Planet. Sci., 7, 443-472, 1979.

Crutzen, P.J., The role of the tropics in atmospheric chemistry, in Geophysiology of Amazonia, edited by R. Dickinson, John Wiley, New York, 1985.

Crutzen, P.J., A.C. Delany, J. Greenberg, P. Haggenson, L. Heid, R. Lueb, 
W. Pollock, W. Seiler, A. Warburg, and P. Zimmerman, Tropospheric chemical composition measurements in Brazil during the dry season, $J$. Atmos. Chem., 2, 233-256, 1985.

Delmas, R., and J. Servant, Echanges biosphere-atmosphere d'azote et de Soufre en zone intertropicale: Transferts entre les ecosystemes foret et savane en Afrique de l'Ouest, Almos. Res., 21. 53-74, 1987.

Efron, B., and R. Tibshirani, Bootstrap methods for standard errors, confidence intervals, and other measures of statistical accuracy, Statist. Sci., 1, 54-77, 1986.

Fan, S.-M., S.C. Wofsy, P.S. Bakwin, and D.J. Jacob, Atmospherebiosphere exchange of $\mathrm{CO}_{2}$ and $\mathrm{O}_{3}$ in the central Amazon forest, J. Geophys. Res., this issue.

Food and Agricultural Organization, Soil map of the world, vol. IV, South America, UNESCO, , Rome, 1971.

Feamside, P.M., Deforestation in the Brazilian Amazon: How fast is it occurring?, Interciencia, 7, 82-88, 1982.

Fitzjarrald, D.R., K.E. Moore, O.S.M. Cabral, J. Scolar, A.O. Manzi, and L.C. deAbreu, Daytime turbulent exchange between the Amazon Forest and the atmosphere, J. Geophys. Res., this issue.

Franken, W.A., and P.R. Leopoldo, Hydrology of catchment areas of central-Amazonian forest streams, in The Amazon: Limnology and Landscape Ecology of a Mighty Tropical River and Its Basin, edited by H. Sioli, Junk, Dordrecht, 1984.

Galbally, I.E., Emission of fixed nitrogen compounds to the atmosphere in remote areas, in Biogeochemical Cycling of Sulfur and Nitrogen in Remote Areas, edited by J.N. Galloway, R.J. Charison, M.O. Andreae, and H. Rodhe, D. Reidel, Hingham, Mass., 1985.

Galbally, I.E., and C.R. Roy, Loss of fixed nitrogen from soils by nitric oxide exhalation, Nalure 275, 734-735, 1978.

Galloway, J.N., and G.E. Likens, Acid precipitation: The importance of nitric acid, Atmos. Environ., 15, 1081-1085, 1981.

Goreau, T.J, and W.Z. de Mello, Effects of deforestation on sources and sinks of atmospheric carbon dioxide, nitrous oxide, and methane from central Amazonian soils and biota during the dry season: A preliminary study, in Proceedings of Workshop on Biogeochemistry of Tropical Rain Forests: Problems for Research, edited by E. Salati, P. Vose, and T. Lovejoy, Centro de Energia Nuclear na Agricultura, Piracicaba, Sao Paulo, Brazil, 1985.

Goreau, T.J., W.A. Kaplan, S.C.Wofsy, M.B.McElroy, F.W. Valois, and S.W. Watson, Production of $\mathrm{NO}_{2}^{-}$and $\mathrm{N}_{2} \mathrm{O}$ by nitrifying bacteria at reduced concentrations of oxygen, Appl. Environ. Microbiol., 40, 526532,1980

Gregory, G.L., E. Browell, L.S. Warren, and C.H. Hudgins, Amazon Basin ozone and aerosol: Wet season observations, J. Geophys. Res., this issue.

Harriss, R.C., S.C. Wofsy, M. Garstang, E.V. Browell, L.C.B. Molion, R.J. McNeal, J.M. Hoell, Jr., R.J. Bendura, S.M. Beck, R.L. Navarro, J.T. Riley, and R.L. Snell, The Amazon Boundary Layer Experiment [ABLE 2A]: Dry season 1985, J. Geophys. Res., 93, 1351-1360, 1988.

Harriss, R.C., et al., The Amazon Boundary Layer Experiment: Wet season 1987, J. Geophys. Res., this issue.

Hill, A.C., Vegetation: A sink for atmospheric pollutants, J. Air Pollut. Contr. Assoc., 21, 341-346, 1971.

Jacob, D.J., and S.C. Wofsy, Photochemistry of biogenic emissions over the Amazon Forest, J. Geophys. Res., 93, 1477-1486, 1988.

Jacob, D.J., and S.C. Wofsy, Budgets of reactive nitrogen, hydrocarbons, and ozone over the Amazon Forest during the wet season, J. Geophys. Res., this issue.

Johansson, C., Pine forest: A negligible sink for atmospheric $\mathrm{NO}_{x}$ in rural Sweden, Tellus, 39, 426-438, 1987.

Johansson, C., and L. Granat, Emission of nitric oxide from arable land, Tellus, 36, 25-37, 1984.

Johansson, C., H. Rodhe, and E. Sanhueza, Emission of NO in a tropical savanna and a cloud forest during the dry season, J. Geophys. Res., 93. 7180-7192, 1988.

Jordan, C.F., W. Caskey, G. Escalante, R. Herrera, F. Montagnini, R.
Todd, and C. Uhl, The nitrogen cycle in a "Terra Firme" rainforest on oxisol in the Amazon territory of Venezuela, Plant and Soil, 67 325-332, 1982.

Judeikis, H.S., and A.G. Wren, Laboratory measurements of $\mathrm{NO}$ and $\mathrm{NO}_{2}$ depositions onto soil and cement surfaces, Atmos. Environ., 12, 23152319, 1978.

Kaplan, W.A., S.C. Wof sy, M. Keller, and J.M. da Costa, Emission of NO and deposition of $\mathrm{O}_{3}$ in a tropical forest system, J. Geophys. Res., 93, 1389-1395, 1988.

Keller, M.K., T.J. Goreau, S.C. Wofsy, W.A. Kaplan, and M.B. McElroy, Production of nitrous oxide and consumption of methane by forest soils, Geophys. Res. Lett., 10, 1156-1159, 1983.

Keller, M.K., W.A. Kaplan, and S.C. Wofsy, Emissions of $\mathrm{N}_{2} \mathrm{O}, \mathrm{CH}_{4}$ and $\mathrm{CO}_{2}$ from tropical forest soils, J. Geophys. Res., 91, 11791-11801, 1986.

Keller, M.K., W.A. Kaplan, S.C. Wofsy, and J.M. da Costa, Emissions of $\mathrm{N}_{2} \mathrm{O}$ from tropical forest soils: Response to fertilization with $\mathrm{NH}_{4}^{+}$, $\mathrm{NO}_{3}^{-}$and $\mathrm{PO}_{3}^{-3}, J$. Geophys. Res., 93, 1600-1604, 1988.

Kirchhoff, V.W.J.H., I.M.O. da Silva, and E.V. Browell, Ozone measurements in Amazonia: Dry season versus wet season, J. Geophys. Res., this issue.

Kisser-Priesack, G.M., I. Scheunert, and G. Gnatz, Uptake of and ${ }^{15} \mathrm{NO}_{2}$ by plant cuticles, Naturwissenschaften, 74, 550-551, 1987.

Levy H., II, Photochemistry of the lower troposphere, Planet. Space Sci., 20, 919-935, 1972.

Lipschultz, F., O.C. Zafiriou, S.C. Wofsy, M.B. McElroy, F.W. Valois, and S.W. Watson, Production of $\mathrm{NO}$ and $\mathrm{N}_{2} \mathrm{O}$ by soil nitrifying bacteria, Nature, 294, 641-643, 1981.

Livingston, G.P., P.M. Vitousek, and P.A. Matson, Nitrous oxide flux and nitrogen transformations across a landscape gradient in Amazonia, $J$. Geophys. Res., 93, 1593-1599, 1988.

Logan, J.A., M.J. Prather, S.C. Wofsy, and M.B. McElroy. Tropospheric chemistry: A global perspective, J. Geophys. Res., 86, 7210-7254, 1981.

Logan, J.A., Nitrogen oxides in the troposphere: Global and regional budgets. J. Geophys. Res., 88, 10785-10807, 1983.

Matson, P.A., P.M. Vitousek, and G.P. Livingston, Sources of variations in nitrous oxide flux from Amazon ecosystems, J. Geophys. Res., this is sue.

McElroy, M.B. and S.C. Wofsy, Tropical forests: Interactions with the atmosphere, in AAAS Symposium Volume: Tropical Forests and World Almosphere, edited by G.T. Prance, pp. 33-60, Westview Press, Boulder, Colo., 1986.

Nelson, D.W., and J.M. Bremner, gaseous products of nitrite decomposition in soils, Soil Biol. Biochem., 2, 203-215, 1970.

Parrish, D.D., E.J. Williams, D.W. Fahey, S.C. Liu, and F.C. Fehsenfeld, Measurement of nitrogen oxide fluxes from soils: Intercomparison of enclosure and gradient measurement techniques, J. Geophys. Res., 92, 2165-2173, 1987.

Payne, W.J., Denitrification, John Wiley, New York, 1981.

Roberts, J., O.M.R. Cabral, and L.F. De Aguiar, Stomatal and boundarylayer conductances measured in a terra firme rain forest, Manaus, Amazonas, Brasil, J. Appl. Ecol., 27, 336-353, 1990.

Shuttleworth, W.J., J.H.C. Gash, C.R. Lloyd, C.J. Moore, J.M. Roberts, A.O. Marques, G.F. Fisch, V. de P. Silva, M.N.G. Ribeiro, L.C.B. Molion, L.D. Abreu Sa, J.C.A. Nobre, O.M.R. Cabral, S.R. Patel, and J.C. de Moraes, Eddy correlation measurements of energy partition for Amazonian forest, Quart. J. Royal Metoer. Soc., 110, 1143-1162, 1984.

Slemr, F., and W. Seiler, Field measurements of $\mathrm{NO}$ and $\mathrm{NO}_{2}$ emissions from fertilized and unfertilized soils, J. Atmos. Chem., 2, 1-24, 1984.

Stark, N., Nutrient cycling, 1, Nutrient distribution in some Amazonian soils, Trop. Ecol., 12, 24-50, 1971.

Torres, A.L., and H. Buchan, Tropospheric nitric oxide measurements over the Amazon Basin, J. Geophys. Res., 93, 1396-1406, 1988.

Trumbore, S.E., M.Keller, S.C.Wofsy, and J.M. da Costa, Measurements of soil and canopy exchange rates in the Amazon rain forest using ${ }^{222} \mathrm{Rn}, J$. Geophys. Res., this issue.

Vitousek, P.M., and R.L. Sanford, Jr., Nutrient cycling in moist tropical forest, Ann. Rev. Ecol. Syst., 17, 137-167, 1986. 
Williams, E.J., D.D. Parrish, and F.C. Fehsenfeld, Determination of nitrogen oxide emissions from soils: results from a grassland site in Colorado, J. Geophys. Res., 92, 2173-2180, 1987.

World Meteorological Organization, Atmospheric ozone 1985: assessment of our understanding of the processes controlling its present distribution and change, WMO Global Ozone Research and Monitoring Project, Rep. 16, Geneva, 1985.

P. S. Bakwin, S.-M. Fan, and S. C. Wofsy, Division of Applied Sciences, Harvard University, Cambridge, MA 02138.
M. Keller, Department of Geology, Princeton University, Princeton, NJ 08544

S. E. Trumbore, Lamont-Doherty Geophysical Observatory, Palisades, NY 10964.

J. M. da Costa, Departmento Engenharea Agricola, Universidad Federal de Vicosa, 36576 Vicosa, Mina Gerais, Brazil.

(Received May 26, 1989;

revised February 6, 1990;

accepted February 6, 1990.) 